\title{
Gebelerin stresle başa çıkma tarzlarının anksiyete ve depresyon düzeyi ile ilişkisi
}

\section{The relationship between anxiety and depression level and coping styles with stress of pregnant women}

\author{
Gülseren Dağlar*, Naim Nur
}

Ebelik Bölümü (Dr. G. Dağlar), Cumhuriyet Üniversitesi Sağlık Bilimleri Fakültesi, TR-58140 Sivas, Halk Sağlığı Anabilim Dalı (Doç. Dr. Naim Nur), Cumhuriyet Üniversitesi Tıp Fakültesi, TR-58140 Sivas

\begin{abstract}
Özet
Amaç. Gebelerin stresle başa çıkma tarzları ile anksiyete ve depresyon düzeyi arasındaki ilişkiyi belirlemektir. Yöntem. Bu çalışma Mart ve Eylül 2013 tarihleri arasında Sivas merkezde basit rastgele örnekleme yöntemiyle seçilen 12 mahallede 227 gebe ile ev ziyareti şeklinde yapılmıștır. Veriler sosyo-demografik kişisel bilgi formu, Stresle Başa Çıkma Tarzları Ölçeği (SBTÖ), Epidemiyolojik Araştırmalar Merkezi Depresyon Skalası (EAMDS) ve Beck Anksiyete Envanteri (BEA) ile toplanmıştır. Bulgular. Gebelerin yaş ortalaması 27,4 $\pm 5,7$ yıldır. EAMDS puan ortalamas1 17,6 $\pm 10,1$ (min-max: 2-55) BAE puan ortalaması da 19,2 $\pm 10,1$ 'dir (min-max: 0-47). Gebelerin \%50,7'sinde depresyon riski saptanmıştır. Gebelerin depresyon ve anksiyete düzeyini çalışma, eğitim düzeyi ve ekonomik durum algısı etkilemiştir. Ayrıca anksiyete düzeyini kronik bir hastalığa sahip olma durumu da etkilemiştir. Stresle başa çıkmada kendine güvenli yaklaşım, iyimser yaklaşım ve sosyal destek arama tarzını kullanma ile gebelikte depresyon riski arasında negatif, boyun eğici ve çaresiz yaklaşım tarzını kullanma ile gebelikte depresyon riski ve anksiyete düzeyi arasında ise pozitif ilişki bulunmuştur. Sonuç. Stresle başa çıkmada kendine güvenli yaklaşım, iyimser yaklaşım ve sosyal destek arama tarzını kullanan gebelerin depresyon riski düşmekte iken, boyun eğici ve çaresiz yaklaşım tarzını kullanan gebelerde ise depresyon riski ve anksiyete düzeyi yükselmektedir.
\end{abstract}

Anahtar sözcükler: Gebelik, stresle başa çıkma tarzı, anksiyete, depresyon

\begin{abstract}
Aim. To determine relationship between anxiety and depression level and coping styles with stress of pregnant women. Method. This study has been conducted in Sivas center between March and September 2013 in twelve districts which was selected by simple random sampling method in the form of home visits with 227 pregnant women. Data were collected by using Sociodemographic Personal Question Form, Ways of Coping with Stress Scale, Center for Epidemiologic Studies Depression Scale (CES-D) and Beck Anxiety Inventory (BAI). Results. Mean age of pregnant women was $27.4 \pm 5.7$. The mean scores CES-D of the pregnant women was $17.6 \pm 10.1$ (minmax: 2-55), mean scores of BAI scores was $19.2 \pm 10.1$ (min-max: 0-47). The risk of depression was found in $50.7 \%$ of pregnant women. Depression and anxiety levels of pregnant women was affected by working status, education level and perception of economic situation. In addition, the level of anxiety was also affected by having a chronic disease. It was determined that there is negative relationship between confident approach, optimistic approach, seeking for social support coping style and the risk of depression during pregnany. Also positive relationship was found between submissive and helpless coping style and risk of depression and anxiety level during pregnancy. Conclusion. Pregnant women who use confident approach, optimistic approach and seeking social support style to cope with stress are at a decreased risk for depression whereas risk of depression and anxiety are at an increased in pregnant women who use submissive and helpless style.
\end{abstract}

Keywords: Pregnancy, stress, coping style, anxiety, depression 
Geliş tarihi/Received: 07 Kasım 2014; Kabul tarihi/Accepted: 10 Aralık 2014

\author{
*İletişim adresi: \\ Dr. Gülseren Dağlar, Ebelik Bölümü, Cumhuriyet Üniversitesi Sağlık Bilimleri Fakültesi, TR- \\ 58140 Sivas. E-posta: gulserendaglar@gmail.com
}

*Bu araştırma, doktora tez çalışmasından üretilmiştir ve Cumhuriyet Üniversitesi Bilimsel
Araştırmalar Projeleri (CÜBAP) birimince desteklenmiştir.

Giriş

Gebelik ve doğum önemli biyolojik değişikliklerin yaşandığı fizyolojik bir süreç olduğu kadar, erken gelişim dönemlerine ilişkin bastırılmış ve çözülmemiş çatışmaların yeniden gündeme geldiği karmaşık psikolojik bir süreçtir. Birçok kadın gebelik ve doğuma bağlı olarak oluşan fizyolojik, psikolojik, sosyal değişimlere kolaylıkla uyum sağlarken, bazı kadınlarda hafif, orta, şiddetli düzeylerde ruhsal sorunlar ortaya çıkmaktadır [1-3]. Gebelik ve doğumun anksiyeteye yol açtığını gösteren çalışmalar bulunmaktadır $[4,5]$. Yapılan bir çalışmada da gebelikte hafif düzeyde depresyon, anksiyete gibi semptomların insidansının arttığı gebelik haftası ilerledikçe depresyon ve anksiyete düzeylerinde değişim yaşandığı saptanmıştır [6].

Gebelikte anksiyete ve depresif belirti görülme sıklı̆̆ gebelik trimesterlerine göre de değişkenlik gösterebilmektedir. Lee ve ark. [7] gebelerin \%54'ünde kayg1, \%37,1'inde depresyon ve her iki durumun da birinci ve üçüncü trimesterlerde daha yaygın ve şiddetli olduğunu bildirmişlerdir. Literatürde gebeliğin ikinci trimesterine göre birinci ve üçüncü trimesterde anksiyete ve depresyonun daha fazla yaşandığı belirtilmektedir [8-11]. Tekgöz ve ark. [12] gebeliğin son 3 ayındaki kadınların, \%50,5'inin bir ya da daha fazla psikiyatrik tanı aldığını \%10,3'ünde depresyon, \%12,1'inde anksiyete, \%28'inde hem depresyon hem de anksiyete olmak üzere en yaygın tanının \% 40,2 ile anksiyete olduğunu saptamıştır.

Gebelerde kaygının artması depresif semptomlara yol açabileceği gibi depresyonunda artması kaygının artmasına neden olabilmekte, sonuçta her iki durumda birbirini etkileyebilmektedir. Şahin ve Kılıçaslan [13] depresyon ile kaygı düzeyi arasında pozitif ilişki olduğunu depresif duygu durumu olanların kaygı düzeyinin de arttığını belirtmiştir. Gebelikte depresyon prevalansı dünyada \%18-58 arasında değişmekte [14-19], ülkemizde de \%12-58 arasında görülmektedir [20-25]. Yapılan çalışmalarda gebelikte yaşanan duygusal gerilimin, özellikle kaygı ve depresyonun, gebelik ve doğum komplikasyonlarını artırdığı, yeni doğanın sağlığını olumsuz etkilediği, erken doğuma, düşük doğum ağırlığına ve intrauterin gelişme geriliğine neden olduğu bildirilmiştir [13, $14,26,27]$.

Gebelik sırasında ve doğum sonrasında kadının anneliğe uyum sağlamaya çalışması, stresin asıl kaynağı olmakla birlikte çevrenin kadından iyi bir anne olmasını beklemesi de stresi artıran bir faktör olabilir [28]. Gebelikte belli düzeylerde stres yaşanabildiğinden gebelerin stresle başa çıkma tarzlarını belirlemek önemlidir. Hamilton ve Lobel [29] bu amaçla yaptıkları çalışmada; gebelerin erken gebelik haftalarında ve ikinci trimesterde sıklıkla spiritüel başa çıkma tarzını kullandıklarını saptamış, Huizink ve ark. [30] da gebelerin ilk trimesterde emosyonel odakl, ikinci trimesterde hem emosyonel hem de problem odaklı başa çıkma tarzlarını kullandıklarını son trimesterde de bunun devam ettiğini bildirmiştir.

Gebelerin stresle başa çıkma tarzlarının anksiyete ve depresyon düzeyini etkileyebileceği düşünüldüğünden bu çalışma gebelerin stresle başa çıkma tarzları ile anksiyete ve depresyon düzeyi arasındaki ilişkiyi belirlemek amacıyla yapılmıştır. 


\section{Gereç ve yöntem}

Kesitsel tipte yapılan araştırmanın evrenini Sivas il merkezinde yaşayan 35 'inci gebelik haftası ve üzerindeki gebeler oluşturmuştur. Sivas il merkezinde bulunan toplam 62 mahallenin \%20'sinin örnekleme alınması hedeflenmiştir. Bu amaçla Selvi'nin [31] çalışmasında sosyoekonomik düzeyi yüksek-orta-düşük olarak belirlediği mahallelerden dörder adet olmak üzere toplam 12 mahalle basit rastgele örnekleme yöntemiyle seçilmiştir. Seçilen mahallelerdeki gebelerin tespiti için ilgili mahallelerin Aile Sağlığı Merkezlerinde (ASM) bulunan gebe kayıtları kullanılmıştır. Seçilen mahallelerde 1 Mart1 Eylül 2013 tarihleri arasında 244 gebe belirlenmiş, bu gebelerden iletişim güçlüğü ve mental yetersizliği olmayan, araştırmaya katılmayı kabul eden tüm gebeler (227 gebe) araştırma kapsamına alınmıştır. Araştırma, ev ziyareti ile gerçekleştirilmiş̧ir. Ev ziyaretinden önce ASM'de gebeyi takip eden aile sağlığı elemanı tarafindan gebenin araştırmaya alınabilme kriterlerine uyup uymadığ 1 değerlendirilerek araştırmaya alınacak gebeler belirlenmiștir. Araştırma kapsamına alınan gebelerin iletişim bilgileri bağlı oldukları ASM'den öğrenilerek gebelere ulaşılmış, ziyaret öncesinde telefon görüşmesi ile ziyaret randevusu alınmış ve ziyaretler yapılmıştır. Yapılan ev ziyaretinde araştırmaya alınabilme kriterlerine uyan gebeler araştırmaya katılmaları için davet edilirken Gönüllü Olur Formundaki bilgiler okunmuş ve onamları alınmıştır. Araştırmaya katılmayı kabul edenlere Sosyo-Demografik Kişisel Bilgi Formu, Stresle Başa Çıkma Tarzları Ölçeği (SBTÖ), Epidemiyolojik Araştırmalar Merkezi Depresyon Skalası (EAMDS) ve Beck Anksiyete Envanteri (BAE) doldurulmuştur. Araştırmanın her aşaması etik ilkelere uygun olarak yürütülmüştür. Sosyo-Demografik Kişisel Bilgi Formunda, gebelerin bazı sosyodemografik özelliklerini (yaş, eğitim düzeyi gibi) ve şimdiki gebeliğe ilişkin özelliklerini (gebelik haftası, gebeliği isteme durumu gibi) içeren sorular yer almaktadır.

Stresle Başa Çıkma Tarzları Ölçeği (SBTÖ); Folkman ve Lazarus (1980) tarafından geliştirilmiştir. Türkiye'de Şahin ve Durak [32] tarafından üniversite öğrencilerine uyarlanan yeni adıyla "Stresle Başa Çıkma Tarzları Ölçeği" 30 maddeden oluşmaktadır. Her bir maddeye verilebilecek tepkiler, bana hiç uygun değil (\%0); bana uygun değil (\%30); bana uygun (\%70); bana çok uygun (\%100) biçiminde dağılım göstermektedir. Ölçekte yer alan 1 ve 9'uncu maddeler ters puanlanmaktadır. Ölçek; Kendine Güvenli Yaklaşım (7 madde), İyimser Yaklaşım (5 madde), Çaresiz Yaklaşım (8 madde), Boyun Eğici Yaklaşım (6 madde), Sosyal Desteğe Başvurma (4 madde) olmak üzere toplam beş alt boyuttan oluşmaktadır. Her bir alt boyuttan alınan puan madde sayısına bölünerek alt grup puanları elde edilmektedir. Alt boyutlardan alınan yüksek puan bireyin söz konusu yaklaşımı daha çok kullandığını göstermektedir.

Epidemiyolojik Araştırmalar Merkezi Depresyon Skalası (EAMDS); depresif semptomları ölçmek üzere tasarlanmış, kısa, genel popülasyona ve özel gruplara uygulanabilen bir ölçektir. Ölçeğin maddeleri depresyonla ilgili semptomlardan oluşmaktadır. Ölçek 20 maddeden oluşmakta, her bir madde 0-3 puan alabilmekte 4, 8, 12 ve 16. maddeler ters puanlanmaktadır. Toplam puan 0-60 arasında değişebilmekte 16 ve üzeri puan depresyon olasılığını düşündürmektedir. Ölçek geçen bir haftayı sorgulamakta ve $0=$ nadiren ya da hiç (haftada 1 gün ya da daha az), 1=ara-sıra (haftada 1-2 gün), 2=sıklıkla (haftada 3-4 gün), 3=çoğu zaman ya da her zaman (haftada 5-7 gün) şeklinde puanlanmaktadır. Ölçeğin Türkçe geçerlilik ve güvenilirliği Yılmaz ve Beji [33] tarafindan yapılmış olup, ölçeğin Cronbach alfa katsayısı 0,85 olarak bulunmuştur.

Beck Anksiyete Envanteri (BAE); anksiyete belirtilerinin sıklığının belirlenmesinde kullanılan, Beck tarafindan geliştirilen 21 maddelik dörtlü likert tipte kendi kendini değerlendirme ölçeğidir. Ölçeğin Türkçe geçerlilik ve güvenilirliği Ulusoy ve ark. [34] tarafindan yapılmış olup, Cronbach alfa katsayısı 0,93 olarak bulunmuştur. BAE'deki maddelerde anksiyetenin subjektif, somatik ve panikle ilgili belirtileri tarif edilmektedir. Her madde 0'dan 3'e kadar puanlanmakta ölçekten alınacak toplam puan 0-63 arasında değişmektedir. 
Toplam puanların yüksekliği bireyin yaşadığı anksiyetenin şiddetini gösterir; 13 madde fizyolojik semptomları değerlendirir, 5 madde kavrama yönünü açıklar ve 3 madde hem somatik, hem de kavrama semptomlarını simgeler.

Verilerin istatistiksel değerlendirmeleri SPSS 14,0 bilgisayar paket programları ile değerlendirilmiştir. İstatistikî değerlendirmelerde; Tanımlayıcı İstatistik Ölçütleri, İki Ortalama Arasındaki Farkın Önemlilik Testi (t testi), Varyans Analizi, Mann-Whitney U Testi, Kruskal Wallis Varyans Analizi ve Korelasyon Katsayısı kullanılmıştır. Anlamlılık p $<0,05$ olarak kabul edilmiştir.

\section{Bulgular}

Gebelerin sosyodemografik ve obstetrik özellikleri; gebelerin \%80,6'sının 20-34 yaş grubunda olduğu saptanmıştır. Gebelerin \%57,7'sinin ilkokul ve ortaokul mezunu olduğu, \%64,8'inin çekirdek ailede yaşadığı, \%84,6'sının çalışmadığ $1, \% 57,7$ 'sinin ekonomik durumunu gelir gidere denk olarak algıladığı ve \%89,9'unun kronik bir hastalığ olmadığ1 belirlenmiştir. Çalışmaya katılan gebelerin yarıya yakınının $(\% 41,8)$ üçüncü ve üzeri gebeliğini yaşadığı, \%37,9'unun bir yaşayan çocuğu olduğu, \%44,9'unun gebeliğini planlamadığı $, \% 30,4$ 'ünün daha önce gebelik kaybı yaşadığı, yaklaşık dörtte üçünün $(\% 74,4)$ sağlıklı gebelik süreci yaşadığı, büyük çoğunluğunun $(\% 93,4)$ düzenli olarak izlem yaptırdığ1, \%64,4’ünün gebeliğini öğrendiğinde, \%75,8'inin de gebeliğinin üçüncü trimesterinde olumlu duygular yaşadığı saptanmıştır.

Çalışmada kullanılan ölçeklerin çalışmaya özgü puan ortalamaları; EAMDS puan ortalamas 17,57 $\pm 10,10$ (min-max: 2-55) ve BAE puan ortalamas1 19,16 $\pm 10,08$ (minmax: 0-47) olarak saptanmıştır. Gebelerin \%50,7'sinde depresyon riski olduğu belirlenmiştir. SBÇTÖ alt boyutlarının kendine güvenli, iyimser, çaresiz ve boyun eğici yaklaşım ile sosyal destek arama puan ortalamalarının sırasıyla 2,04 $\pm 0,53$ (min-max: 0,14-3); 1,82 $\pm 0,59$ (min-max: 0,40-3); 1,26 $\pm 0,56$ (min-max: 0-2,87); 1,01 $\pm 0,48$ (minmax: 0-2,50); 1,91 $\pm 0,59$ (min-max: 0,25-3) olduğu bulunmuştur.

Gebelerin depresyon ve anksiyete düzeylerine ilişkin bulgular; çalışmaya katılan ilkokul ve ortaokul mezunu gebelerin depresyon ve anksiyete puan ortalamaları lise ve üzeri eğitime sahip gebelerin puan ortalamalarından, çalışmayanların depresyon ve anksiyete puan ortalamaları da çalışanlarınkinden anlamlı düzeyde yüksek bulunmuştur (sırasıyla $\mathrm{p}=0,008 ; \mathrm{p}=0,009 ; \mathrm{p}=0,001 ; \mathrm{p}=0,004)$. Geliri giderinden fazla algilayan grubun depresyon puan ortalaması geliri giderinden az algılayan gruptan anlamlı olarak daha düşük, geliri giderinden az algılayan grubun anksiyete puan ortalaması da diğer grupların anksiyete puan ortalamalarından anlamlı olarak yüksek belirlenmiştir $(\mathrm{p}=0,037 ; \mathrm{p}=0,001)$. Yaş, aile tipi ve kronik hastalık varlığının gebelerin depresyon puan ortalamaları arasında, yaş ve aile tipinin de anksiyete düzeyi üzerinde anlamlı fark oluşturmadığı ( $p>0,05)$, kronik hastalığı olmayan gebelerin ise anksiyete puan ortalamalarının kronik hastalığ olanlara göre anlamlı düzeyde yüksek olduğu belirlenmiştir $(\mathrm{p}=0,007)$ (Tablo 1).

Gebelerin gebelik ve yaşayan çocuk sayısı, planlı gebelik yaşama, gebelik kaybı yaşama, gebelik izlemi yaptırma, izlem yeri, bebeğin istenen cinsiyette olmasına göre depresyon ve anksiyete puan ortalamaları arasında anlamlı düzeyde fark saptanmamıştır ( $>>0,05)$. Gebelerin gebeliğini öğrendiğindeki ve üçüncü trimesterde yaşadıkları hislerine göre depresyon puan ortalamaları arasında istatistiksel olarak anlamlı fark olduğu $(p<0,05)$, anksiyete puan ortalamaları arasında ise anlamlı fark olmadığ Gebe kaldığını öğrendiğinde ve üçüncü trimesterde olumsuz duygu yaşayanların depresyon puan ortalaması olumlu duygu yaşayanlara göre yüksek bulunmuştur $(p<0,05)$. Riskli gebelik yaşayan ve yaşamayan gebelerin depresyon puan ortalamaları arasında anlamlı düzeyde fark saptanmamışken $(\mathrm{p}>0,05)$ riskli gebelik süreci yaşayan gebelerin anksiyete düzeyleri sağlıklı gebelik süreci yaşayanlara göre anlamlı düzeyde yüksek belirlenmiştir $(\mathrm{p}=0,009)$ (Tablo 2). 
Tablo 1. Gebelerin sosyo-demografik özelliklerine göre stresle başa çıkma, depresyon ve anksiyete puan ortalamalarının karşılaştırılması.

\begin{tabular}{|c|c|c|c|c|c|c|c|}
\hline \multicolumn{8}{|c|}{ Stresle başa çıkma tarzları ölçeği } \\
\hline Özellikler & $\begin{array}{l}\text { Kendine } \\
\text { güvenli } \\
\text { yaklaşım } \\
\end{array}$ & $\begin{array}{l}\text { İyimser } \\
\text { yaklaşım }\end{array}$ & $\begin{array}{l}\text { Çaresiz } \\
\text { yaklaşım }\end{array}$ & $\begin{array}{l}\text { Boyun eğici } \\
\text { yaklaşım }\end{array}$ & $\begin{array}{l}\text { Sosyal destek } \\
\text { arama }\end{array}$ & EAMDS & BAE \\
\hline & $\overline{\overline{\mathbf{x}}} \pm \mathrm{S}$ & $\overline{\mathbf{x}} \pm S$ & $\overline{\mathbf{x}} \pm S$ & $\overline{\mathbf{x}} \pm S$ & $\overline{\mathbf{x}} \pm S$ & $\overline{\mathbf{x}} \pm S$ & $\overline{\mathbf{x}} \pm S$ \\
\hline \multicolumn{8}{|l|}{ Yaş } \\
\hline$<20$ yaş $^{a}(\mathrm{n}: 12)$ & $1,97 \pm 0,54$ & $2,05 \pm 0,70$ & $1,40 \pm 0,43$ & $0,99 \pm 0.47$ & $1,87 \pm 0,37$ & $20,25 \pm 8,43$ & $21,75 \pm 8.82$ \\
\hline $\begin{array}{l}20-34 \text { yaş }^{b} \\
(n: 183)\end{array}$ & $2,04 \pm 0,53$ & $1,83 \pm 0,55$ & $1,24 \pm 0,54$ & $1,00 \pm 0.48$ & $1,90 \pm 0,60$ & $16,98 \pm 9,85$ & $18,85 \pm 10.17$ \\
\hline$>34 \operatorname{yaş}^{c}(\mathrm{n}: 32)$ & $2,08 \pm 0,55$ & $1,72 \pm 0,72$ & $1,33 \pm 0,70$ & $1,09 \pm 0.47$ & $2,00 \pm 0,62$ & $20,00 \pm 11,74$ & $19,97 \pm 10.14$ \\
\hline P Değeri * & 0,751 & 0,198 & 0,387 & 0,610 & 0,599 & 0,126 & 0,456 \\
\hline \multicolumn{8}{|c|}{ Eğitim durumu } \\
\hline $\begin{array}{l}\text { Lise öncesi } \\
(\mathrm{n}: 131)\end{array}$ & $2,04 \pm 0,54$ & $1,85 \pm 0,59$ & $1,36 \pm 0,59$ & $1,12 \pm 0,47$ & $1,85 \pm 0,59$ & $19,08 \pm 10,29$ & $20,65 \pm 10,67$ \\
\hline $\begin{array}{l}\text { Lise ve üzeri } \\
(\mathrm{n}: 96)\end{array}$ & $2,05 \pm 0,52$ & $1,79 \pm 0,59$ & $1,13 \pm 0,48$ & $0,86 \pm 0,44$ & $2,01 \pm 0,58$ & $15,52 \pm 9,50$ & $17,13 \pm 8,87$ \\
\hline P Değeri ** & 0,967 & 0,455 & 0,002 & 0,001 & 0,046 & 0,008 & 0,009 \\
\hline \multicolumn{8}{|l|}{ Aile tipi } \\
\hline $\begin{array}{l}\text { Çekirdek aile } \\
\text { (n:147) }\end{array}$ & $2,11 \pm 0,49$ & $1,83 \pm 0,60$ & $1,21 \pm 0,52$ & $0,97 \pm 0,44$ & $1,93 \pm 0,59$ & $\begin{array}{l}17,19 \pm 10 \\
40\end{array}$ & $18,68 \pm 9,74$ \\
\hline $\begin{array}{l}\text { Geniş aile } \\
(\mathrm{n}: 80)\end{array}$ & $1,92 \pm 0,58$ & $1,81 \pm 0,57$ & $1,36 \pm 0,61$ & $1,09 \pm 0,52$ & $1,89 \pm 0,59$ & $18,29 \pm 9,55$ & $20,06 \pm 10,69$ \\
\hline P Değeri ** & 0,008 & 0,734 & 0,047 & 0,069 & 0,645 & 0,436 & 0,325 \\
\hline \multicolumn{8}{|c|}{ Çalıșma durumu } \\
\hline Çalışan (n:35) & $2,09 \pm 0,40$ & $1,92 \pm 0,46$ & $0,91 \pm 0,47$ & $0,80 \pm 0,39$ & $2,22 \pm 0,55$ & $12,34 \pm 7,67$ & $14,71 \pm 8,53$ \\
\hline $\begin{array}{l}\text { Çalışmayan } \\
(\mathrm{n}: 192)\end{array}$ & $2,04 \pm 0,55$ & $1,81 \pm 0,61$ & $1,33 \pm 0,55$ & $1,05 \pm 0,48$ & $1,86 \pm 0,58$ & $18,53 \pm 10,21$ & $19,98 \pm 10,15$ \\
\hline P Değeri $* *$ & 0,556 & 0,291 & 0,000 & 0,004 & 0,001 & 0,001 & 0,004 \\
\hline \multicolumn{8}{|c|}{ Ekonomik durum algısı } \\
\hline $\begin{array}{l}\text { Gelirim } \\
\text { giderimden } \mathrm{az}^{\mathrm{a}} \\
(\mathrm{n}: 73)\end{array}$ & $2,07 \pm 0,50$ & $1,78 \pm 0,57$ & $1,37 \pm 0,60$ & $1,13 \pm 0,44$ & $1,81 \pm 0,60$ & $19,89 \pm 11,41$ & $21,70 \pm 11,01$ \\
\hline $\begin{array}{l}\text { Gelirim } \\
\text { giderime denk }{ }^{b} \\
(\mathrm{n}: 131)\end{array}$ & $2,02 \pm 0,54$ & $1,82 \pm 0,61$ & $1,25 \pm 0,51$ & $0,99 \pm 0,49$ & $1,94 \pm 0,59$ & $16,79 \pm 8,71$ & $18,80 \pm 9,52$ \\
\hline $\begin{array}{l}\text { Gelirim } \\
\text { giderimden } \\
\text { fazla }^{c}(n: 23)\end{array}$ & $2,10 \pm 0,58$ & $1,94 \pm 0,49$ & $0,99 \pm 0,55$ & $0,81 \pm 0,41$ & $2,13 \pm 0,55$ & $14,70 \pm 12,00$ & $13,22 \pm 7,27$ \\
\hline P Değeri * & 0,578 & 0,550 & 0,021 & 0,013 & 0,054 & 0,037 & 0,001 \\
\hline Anlamlı fark & & & $a>c$ & $a>c$ & & $\mathrm{c}<\mathrm{a}$ & $c<a, b$ \\
\hline \multicolumn{8}{|c|}{ Kronik hastalık durumu } \\
\hline $\operatorname{Var}(\mathrm{n}: 23)$ & $2,13 \pm 0,59$ & $1,92 \pm 0,61$ & $1,29 \pm 0,58$ & $1,01 \pm 0,45$ & $2,01 \pm 0,65$ & $17,17 \pm 9,80$ & $18,47 \pm 9,68$ \\
\hline Yok (n:204) & $2,04 \pm 0,52$ & $1,81 \pm 0,59$ & $1,26 \pm 0,55$ & $1,01 \pm 0,48$ & $1,90 \pm 0,58$ & $21,22 \pm 12,11$ & $25,34 \pm 11,65$ \\
\hline P Değeri *** & 0,264 & 0,466 & 0,897 & 0,989 & 0,479 & 0,121 & 0,007 \\
\hline
\end{tabular}

\section{Gebelerin stresle başa çıkma tarzlarına ilişkin bulgular}

Lise ve üzeri eğitime sahip gebelerin çaresiz ve boyun eğici yaklaşım puanı ilköğrenim mezunu olanlardan daha düşük (sırasıyla $\mathrm{p}<0,002 ; \mathrm{p}<0,001$ ), sosyal destek arama boyutunda ise lise ve üzeri eğitime sahip gebelerin puanı ilkokul ve ortaokul mezunu olanlardan daha yüksek $(\mathrm{p}=0,046)$ saptanmıştır. Çekirdek aile yapısına sahip olanların kendine güvenli yaklaşım puan ortalamalarının geniş aile yapısına sahip olanlarınkinden, çaresiz yaklaşım boyutunda da geniş aile yapısına sahip olanların puan ortalamalarının çekirdek aile yapısına sahip olanlarınkinden anlamlı olarak daha yüksek saptanmıştır (sırasıyla $\mathrm{p}=0,008, \mathrm{p}=0,047$ ). Çalışmayan kadınların çaresiz ve boyun eğici yaklaşım puan ortalamaları çalışanlarınkinden istatistiksel olarak anlamlı düzeyde daha yüksek (sırasıyla $\mathrm{p}=0,000 ; \mathrm{p}=0,004)$ iken sosyal destek arama boyutunda ise anlamlı düzeyde daha düşük bulunmuştur $(\mathrm{p}=0,001)$. Geliri giderinden az algılayan gebelerin çaresiz ve boyun eğici yaklaşım puan ortalamaları geliri giderine eşit ve fazla olanlardan anlamlı olarak yüksek (sırasıyla $\mathrm{p}=0,021$ ve $\mathrm{p}=0,013$ ) saptanmıştır. Gebelerin yaş gruplarına ve kronik hastalık durumuna göre SBTÖ alt boyutları arasında istatistiksel olarak anlamlı fark olmadığ belirlenmiştir ( $\mathrm{p}>0,05)$ (Tablo 1). 
Gebelerin gebelik sayısına göre SBTÖ alt boyutlarından boyun eğici yaklaşım puan ortalamaları arasında istatistiksel olarak anlamlı fark olduğu $(p=0,019)$, diğer başa çıkma tarzları arasında ise anlamlı fark olmadığı saptanmıştır $(\mathrm{p}>0,05)$. Üç ve üzeri gebeliğini yaşayanların boyun eğici yaklaşım puan ortalaması ilk gebeliğini yaşayanlara göre yüksek bulunmuştur $(\mathrm{p}=0,019)$. Çocuğu olmayan grupta bulunan kadınların iyimser yaklaşım puan ortalaması bir çocuğu olan kadınların iyimser yaklaşım puan ortalamasından, iki ve üzeri çocuğu olan kadınların boyun eğici yaklaşım puan ortalaması çocuğu olmayan kadınların boyun eğici yaklaşım puan ortalamasından anlamlı olarak yüksek saptanmıştır (sırasıyla $\mathrm{p}=0,042 ; \mathrm{p}=0,011$ ). Gebelik kaybı yaşayanların boyun eğici yaklaşım puan ortalamasının gebelik kaybı yaşamayanlara göre anlamlı düzeyde yüksek olduğu bulunmuştur ( $\mathrm{p}=0,030$ ). Düzenli izlem yaptıranlarda kendine güvenli yaklaşım ve sosyal destek arama boyutlarının puan ortalamaları, düzenli izlem yaptırmayanlarda ise çaresiz yaklaşım ve boyun eğici yaklaşım puan ortalamaları anlamlı düzeyde yüksek bulunmuştur (sırasıyla $\mathrm{p}=0,017 ; \mathrm{p}=0,029 ; \mathrm{p}=0,036 ; \mathrm{p}=0,014$ ). Gebelik izlemini devlet, üniversite ve özel hastanede karışık olarak yaptıranların sosyal destek arama puan ortalaması gebelik izlemini üniversite hastanesinde yaptıranlarınkinden anlamlı düzeyde yüksek saptanmıştır $(\mathrm{p}=0,046)$. Gebeliğini öğrendiklerinde olumlu duygular yaşayanların kendine güvenli yaklaşım puan ortalaması olumsuz duygular yaşayanlara göre anlamlı düzeyde yüksek bulunmuştur ( $\mathrm{p}=0,011$ ). Gebe kalmayı planlama, gebelikte riskli durum yaşama, bebeğin cinsiyetini isteme durumu ve gebeliğin üçüncü trimesterindeki hislere göre SBTÖ alt boyutları puan ortalamaları arasında anlamlı fark saptanmamıştır $(p>0,05)$ (Tablo 2).

Stresle başa çıkma tarzlarından kendine güvenli yaklaşım, iyimser yaklaşım ve sosyal destek arama puan ortalamaları ile depresyon puan ortalamaları arasinda negatif, boyun eğici ve çaresiz yaklaşım puan ortalamaları ile depresyon puan ortalamaları arasında ise pozitif ilişki saptanmıştır. Ayrıca boyun eğici ve çaresiz yaklaşım puan ortalamaları ile anksiyete puan ortalamaları arasında da pozitif ilişki saptanmıştır (Tablo 3). 
Tablo 2. Gebelerin obstetrik özelliklerine göre stresle başa çıkma, depresyon ve anksiyete puan ortalamalarının karşılaştırılması.

\begin{tabular}{|c|c|c|c|c|c|c|c|}
\hline \multirow[b]{2}{*}{ Özellikler } & \multicolumn{7}{|c|}{ Stresle Başa Çıkma Tarzları Ölçeği } \\
\hline & $\begin{array}{l}\text { Kendine } \\
\text { güvenli } \\
\text { yaklaşım } \\
\end{array}$ & $\begin{array}{l}\text { İyimser } \\
\text { yaklaşım }\end{array}$ & $\begin{array}{l}\text { Çaresiz } \\
\text { yaklaşım }\end{array}$ & $\begin{array}{l}\text { Boyun eğici } \\
\text { yaklaşım }\end{array}$ & $\begin{array}{l}\text { Sosyal destek } \\
\text { arama }\end{array}$ & EAMDS & BAE \\
\hline & $\overline{\overline{\mathbf{x}}} \pm \mathrm{S}$ & $\overline{\bar{x}} \pm S$ & $\overline{\bar{x}} \pm S$ & $\overline{\bar{x}} \pm S$ & $\overline{\bar{x}} \pm S$ & $\overline{\bar{x}} \pm S$ & $\overline{\bar{x}} \pm S$ \\
\hline \multicolumn{8}{|l|}{ Gebelik say1sı } \\
\hline 1 gebelik $^{\mathrm{a}}(\mathrm{n}: 61)$ & $2,07 \pm 0,48$ & $1,90 \pm 0,55$ & $1,26 \pm 0,55$ & $0,90 \pm 0,48$ & $2,03 \pm 0,51$ & $17,27 \pm 10,36$ & $18,96 \pm 9,10$ \\
\hline 2 gebelik $^{b}(\mathrm{n}: 71)$ & $2,00 \pm 0,56$ & $1,79 \pm 0,60$ & $1,22 \pm 0,58$ & $0,97 \pm 0,45$ & $1,82 \pm 0,60$ & $16,49 \pm 9,61$ & $17,83 \pm 9,66$ \\
\hline 3 ve üzeri gebelik $^{\mathrm{c}}$ (n: 95) & $2,06 \pm 0,54$ & $1,80 \pm 0,60$ & $1,31 \pm 0,55$ & $1,11 \pm 0,48$ & $1,91 \pm 0,63$ & $18,57 \pm 10,29$ & $20,29 \pm 10,92$ \\
\hline P Değeri * & 0,721 & 0,468 & 0,601 & 0,019 & 0,114 & 0,407 & 0,294 \\
\hline Anlamlı fark & & & & $c>a$ & & & \\
\hline \multicolumn{8}{|l|}{ Yaşayan çocuk sayısı } \\
\hline Yok $^{\text {a }}(\mathrm{n}: 77)$ & $2,11 \pm 0,45$ & $1,95 \pm 0,52$ & $1,23 \pm 0,54$ & $0,91 \pm 0,47$ & $1,97 \pm 0,51$ & $16,02 \pm 9,89$ & $18,14 \pm 9,53$ \\
\hline $1^{\mathrm{b}}(\mathrm{n}: 86)$ & $2,03 \pm 0,58$ & $1,72 \pm 0,61$ & $1,26 \pm 0,56$ & $1,00 \pm 0,46$ & $1,84 \pm 0,61$ & $17,47 \pm 9,75$ & $18,90 \pm 9,66$ \\
\hline 2 ve üzeri ${ }^{c}$ (n:64) & $1,98 \pm 0,54$ & $1,81 \pm 0,61$ & $1,31 \pm 0,57$ & $1,15 \pm 0,47$ & $1,94 \pm 0,65$ & $19,57 \pm 10,61$ & $20,75 \pm 11,18$ \\
\hline P Değeri * & 0,304 & 0,042 & 0,713 & 0,011 & 0,374 & 0,114 & 0,298 \\
\hline Anlamlı fark & & $a>b$ & & $c>a$ & & & \\
\hline \multicolumn{8}{|l|}{ Gebe kalmayı planlama } \\
\hline Planlı (n:125) & $2,09 \pm 0,47$ & $1,82 \pm 0,56$ & $1,20 \pm 0,55$ & $1,02 \pm 0,48$ & $1,92 \pm 0,55$ & $16,90 \pm 9,46$ & $19,11 \pm 9,37$ \\
\hline Planlı değil (n:102) & $1,99 \pm 0,59$ & $1,83 \pm 0,62$ & $1,34 \pm 0,56$ & $1,00 \pm 0,47$ & $1,90 \pm 0,64$ & $18,40 \pm 10,81$ & $19,23 \pm 10,94$ \\
\hline P Değeri ** & 0,173 & 0,871 & 0,053 & 0,781 & 0,791 & 0,267 & 0,927 \\
\hline \multicolumn{8}{|l|}{ Gebelik kaybı yaşama } \\
\hline Evet (n:69) & $2,12 \pm 0,54$ & $1,87 \pm 0,62$ & $1,30 \pm 0,56$ & $1,12 \pm 0,49$ & $1,90 \pm 0,57$ & $17,46 \pm 10,56$ & $19,47 \pm 10,66$ \\
\hline Hayır (n:158) & $2,01 \pm 0,52$ & $1,80 \pm 0,58$ & $1,25 \pm 0,55$ & $0,97 \pm 0,46$ & $1,92 \pm 0,60$ & $17,62 \pm 9,92$ & $19,03 \pm 9,85$ \\
\hline P Değeri $* *$ & 0,152 & 0,429 & 0,523 & 0,030 & 0,877 & 0,911 & 0,760 \\
\hline \multicolumn{8}{|l|}{ Riskli gebelik durumu } \\
\hline Riskli (n:58) & $2,15 \pm 0,59$ & $1,80 \pm 0,64$ & $1,29 \pm 0,62$ & $0,98 \pm 0,51$ & $2,02 \pm 0,58$ & $19,17 \pm 9,23$ & $22,15 \pm 10,02$ \\
\hline Riskli değil (n:169) & $2,01 \pm 0,50$ & $1,83 \pm 0,57$ & $1,26 \pm 0,53$ & $1,02 \pm 0,47$ & $1,88 \pm 0,59$ & $17,02 \pm 10,35$ & $18,14 \pm 9,92$ \\
\hline $\mathrm{P}$ değeri ** & 0,779 & 0,752 & 0,712 & 0,551 & 0,126 & 0,164 & 0,009 \\
\hline \multicolumn{8}{|l|}{ Gebelik izlem durumu } \\
\hline Düzenli (n:212) & $2,07 \pm 0,50$ & $1,85 \pm 0,58$ & $1,24 \pm 0,55$ & $0,99 \pm 0,47$ & $1,94 \pm 0,58$ & $17,15 \pm 9,75$ & $19,26 \pm 10,19$ \\
\hline Düzenli değil (n:15) & $1,65 \pm 0,74$ & $1,52 \pm 0,64$ & $1,57 \pm 0,57$ & $1,32 \pm 0,45$ & $1,58 \pm 0,65$ & $23,53 \pm 13,18$ & $17,80 \pm 8,60$ \\
\hline $\mathrm{P}$ değeri $* * *$ & 0,017 & 0,080 & 0,036 & 0,014 & 0,029 & 0,057 & 0,679 \\
\hline \multicolumn{8}{|l|}{ Gebelik izlem yeri } \\
\hline Devlet hastanesi ${ }^{\text {a }}$ (n:146) & $2,02 \pm 0,53$ & $1,82 \pm 0,60$ & $1,32 \pm 0,61$ & $1,05 \pm 0,46$ & $1,89 \pm 0,56$ & $17,79 \pm 10,41$ & $19,57 \pm 10,42$ \\
\hline $\begin{array}{l}\text { Üniversite hastanes } \mathrm{i}^{\mathrm{b}} \\
(\mathrm{n}: 16)\end{array}$ & $2,19 \pm 0,49$ & $1,77 \pm 0,64$ & $1,16 \pm 0,44$ & $1,01 \pm 0,37$ & $1,60 \pm 0,66$ & $19,56 \pm 7,44$ & $19,87 \pm 8,71$ \\
\hline Özel Hastane ${ }^{c}$ (n:37) & $2,20 \pm 0,50$ & $1,91 \pm 0,49$ & $1,15 \pm 0,42$ & $0,92 \pm 0,48$ & $1,97 \pm 0,66$ & $15,10 \pm 9,64$ & $17,16 \pm 9,90$ \\
\hline $\begin{array}{l}\text { Devlet, üniversite ve özel } \\
\text { hastane }^{d}(\mathrm{n}: 28)\end{array}$ & $1,91 \pm 0,56$ & $1,74 \pm 0,63$ & $1,19 \pm 0,43$ & $0,92 \pm 0,58$ & $2,11 \pm 0,55$ & $18,57 \pm 10,26$ & $19,28 \pm 9,35$ \\
\hline P Değeri $* * * *$ & 0,098 & 0,668 & 0,234 & 0,340 & 0,046 & 0,369 & 0,621 \\
\hline Anlamlı fark & & & & & $\mathrm{d}>\mathrm{b}$ & & \\
\hline \multicolumn{8}{|c|}{ Bebeğin cinsiyetini isteme durumu } \\
\hline İsteyen (n:150) & $2,04 \pm 0,52$ & $1,81 \pm 0,59$ & $1,29 \pm 0,52$ & $0,98 \pm 0,46$ & $1,87 \pm 0,52$ & $17,52 \pm 10,10$ & $19,20 \pm 9,81$ \\
\hline İstemeyen (n:77) & $2,05 \pm 0,55$ & $1,85 \pm 0,58$ & $1,21 \pm 0,61$ & $1,07 \pm 0,50$ & $2,00 \pm 0,71$ & $17,68 \pm 10,16$ & $19,09 \pm 10,65$ \\
\hline P Değeri ** & 0,880 & 0,567 & 0,327 & 0,205 & 0,134 & 0,906 & 0,935 \\
\hline \multicolumn{8}{|c|}{ Gebeliğini öğrendiklerindeki hisleri } \\
\hline $\begin{array}{l}\text { Olumlu duygulanım } \\
(\mathrm{n}: 153)\end{array}$ & $2,11 \pm 0,49$ & $1,86 \pm 0,55$ & $1,22 \pm 0,54$ & $1,00 \pm 0,46$ & $1,95 \pm 0,54$ & $16,55 \pm 9,64$ & $18,59 \pm 9,37$ \\
\hline $\begin{array}{l}\text { Olumsuz duygulanım } \\
(\mathrm{n}: 74)\end{array}$ & $192 \pm 0,59$ & $1,75 \pm 0,66$ & $1,36 \pm 0,58$ & $1,04 \pm 0,50$ & $1,83 \pm 0,68$ & $19,68 \pm 10,75$ & $20,35 \pm 11,39$ \\
\hline P Değeri ** & 0,011 & 0,205 & 0,067 & 0,574 & 0,190 & 0,028 & 0,219 \\
\hline \multicolumn{8}{|c|}{ Gebeliğin 3, trimesterindeki hisleri } \\
\hline $\begin{array}{l}\text { Olumlu duygulanım } \\
(\mathrm{n}: 172)\end{array}$ & $2,06 \pm 0,54$ & $1,86 \pm 0,59$ & $1,26 \pm 0,55$ & $1,00 \pm 0,49$ & $1,94 \pm 0,60$ & $16,35 \pm 9,05$ & $18,47 \pm 10,07$ \\
\hline $\begin{array}{l}\text { Olumsuz duygulanım } \\
(\mathrm{n}: 55)\end{array}$ & $1,99 \pm 0,49$ & $1,69 \pm 0,57$ & $1,27 \pm 0,58$ & $1,05 \pm 0,44$ & $1,83 \pm 0,56$ & $21,40 \pm 12,16$ & $21,32 \pm 9,89$ \\
\hline P Değeri ** & 0,373 & 0,062 & 0,905 & 0,521 & 0,241 & 0,001 & 0,068 \\
\hline
\end{tabular}

Tablo 3. Gebelerin stresle başa çıkma tarzlarının depresyon ve anksiyete düzeyi ile ilişkisi.

\begin{tabular}{lllll}
\hline Stresle başa çıma tarzları & \multicolumn{3}{l}{ EAMDS } & BAE \\
\cline { 2 - 5 } & $\mathbf{P}$ & $\mathbf{R}$ & $\mathbf{P}$ & $\mathbf{R}$ \\
\hline Kendine güvenli yaklaşım & 0,009 & $-0,174$ & 0,908 & $-0,008$ \\
İyimser yaklaşım & 0,000 & $-0,254$ & 0,077 & $-0,117$ \\
Çaresiz yaklaşım & 0,000 & 0,530 & 0,000 & 0,446 \\
Boyun eğici yaklaşım & 0,000 & 0,291 & 0,000 & 0,241 \\
Sosyal destek arama & 0,024 & $-0,149$ & 0,761 & 0,020 \\
\hline
\end{tabular}




\section{Tartışma}

Literatürde bildirilen gebelik dönemi depresyon sıklı̆̆ ile ilgili yurt dışı [14-19] ve yurt içi [20-25] çalışma sonuçları ile uyumlu olarak çalışmaya katılan gebelerin \%50,7'sinde depresyon riski bulunmuştur.

Çalışmaya alınan gebelerin depresyon düzeyinin eğitim ve çalışma durumundan, ekonomik durum algısından etkilendiği sonuçları ile uyumlu olarak eğitimin $[15,21,22$, $24,25,35-37]$, çalışma durumunun $[13,24,25]$ ve ekonomik durumun depresyon düzeyi üzerinde etkili olduğunu $[13,22,24,25,36,38]$ gösteren çalışmalar bulunmaktadır. Gebenin yaşının, aile tipinin ve kronik bir hastalığa sahip olma durumunun ise gebelikte depresyon düzeyini etkilemediği belirlenmiştir. Daha önce yapılan araştırmalarda da; elde ettiğimiz verilerle uyumlu olarak yaşı $[12,15,21,36,39,40]$ aile tipinin $[13,21,25,41$, 42] gebelikte depresyon düzeyini etkilemediği bulunmuştur.

Çalışma bulgularıyla benzer şekilde; yaşayan çocuk sayısının [43] gebeliğin istenme durumunun [21, 36, 39], önceki gebeliklerinde kayıp yaşamış olmanın [21], gebelik döneminde sorun yaşamanın [22] ve cinsiyet beklentisinin [21,39] gebelikte depresyon düzeyini etkilemediği gösterilmiştir. Karataylı [10] ile Şahin ve Kilıçaslan'ın [13] çalışmalarındaki bulgularla paralel olacak şekilde gebe olduklarını öğrenince olumlu duygulanım yaşayan kadınlarda depresyon düzeyinin daha düşük, gebeliklerini öğrendiklerinde ve üçüncü trimesterde korku, endişe, tedirginlik, üzüntü gibi olumsuz duygular yaşayanların ise depresyon düzeyinin yüksek olduğu görülmüştür.

Gebelikte doğuma yakın dönemde anksiyete düzeyi gebeliğin diğer dönemlerine ve doğum sonrası döneme göre daha yüksek olabilir. Yapılan bir çalışmada gebelikte anksiyete insidansının \%6,8 ile 59,5 arasında değiştiği belirlenmiştir [44]. Artan anksiyetenin nedeni gebelik seyri, gebenin kendi ve bebeğin sağlığıyla ilgili endişeleri ve yaklaşan doğuma bağlı duyulan korku olabilir [3,45]. Çalışmada kullanılan BAE'den alınabilecek puan min-max: 0-47 arasında olup gebelerin anksiyete puan ortalamaları $19,2 \pm 10,1$ olarak saptanmıştır.

Bazı çalışmalarda eğitim düzeyi düşük olan gebelerin, anksiyete düzeylerinin yüksek olduğu ve aradaki farkın istatistiksel olarak anlamlı olduğunun [3, 45] saptanması bizim çalışma sonuçlarımız ile benzerlik göstermektedir. Anne adaylarını endişelendiren bir başka konu da ekonomik faktörlerdir. Bebeğin doğumunun ve sonrasının gerektirdiği harcamalar anne adayında anksiyeteye neden olabilir. Çalışmada ekonomik durumu düşük olanlarda anksiyetenin daha yüksek olmasının sebebi bu olabilir. Dülgerler ve ark. [46] çalışmasında buldukları sonuç (gelirlerinin giderlerinden az olduğunu ifade eden gebelerin anksiyete düzeylerinin istatistiksel olarak anlamlı düzeyde yüksek olduğu) bu çalışmada ulaşılan sonuçla uyumludur. Yapılan önceki araştırmalardan [3, 12, 13, 21, 43] farklı olarak bu araştırmada, çalışmayan gebelerin anksiyete düzeyi çalışanlara göre anlamlı düzeyde yüksek saptanmıştır.

Çalışmaya katılan gebelerin obstetrik özelliklerine göre anksiyete düzeyini sadece riskli gebelik durumu etkilemiş, riskli gebelik yaşayanların anksiyete düzeyi yaşamayanlara göre anlamlı düzeyde yüksek bulunmuştur. Yapılan çalışmalarda riskli gebeliklerin anksiyeteye yol açabileceği [47], gebelikte anne ya da fetüsü ilgilendiren fiziksel sorun varlığında psikiyatrik rahatsızlık görülme oranının anlamlı derecede arttığı [48], doğum öncesi depresyon ve/veya anksiyete ile erken kasılmalara bağlı başvuru, planlı sezaryen ile doğum, doğumda epidural analjezi kullanımı ve travayın gebe tarafından daha uzun hissedilmesi arasında anlamlı ilişki olduğu [49] bulunmuştur. Bu çalışma sonuçlarının araştırmada ulaşılan bulgularla uyumlu olduğu görülmektedir.

Çalışma sonuçlarını destekler nitelikteki bazı araştırmalarda; kadınların primigravida ve multigravida olma durumlarına göre doğum öncesi anksiyete düzeyleri arasında fark olmadığ $[40,43,45]$, gebeliğini planlamamış olanların anksiyete ortalamalarının genel ortalamadan farklı çıkmadığı [12, 40,43], gebeliği isteme ve doğacak bebeğin cinsiyetini 
bilme [3, 39] ve düşük yapma [21], gebe olduğunu öğrenince sevinme durumu [13] ile anksiyete puanları arasında ilişki olmadığı sonuçları elde edilmiştir. Araştırmada ulaşılan bu sonuçlar ve destekleyen çalışmalar genelde her gebe kadının gebelik ve doğuma ilişkin kaygı yaşadığını göstermektedir.

Gebelik kadının yaşamında önemli bir yere sahip olmakla birlikte gebelikte oluşan fizyolojik ve psikolojik değişikliklerden dolayı gelişimsel kriz ya da kritik bir dönem olarak değerlendirildiğinden [8] gebenin stresle baş etme yöntemlerinin belirlenmesi önemlidir. Çalışmada SBÇTÖ alt boyutları puan ortalamaları kendine güvenli yaklaşım $2,04 \pm 0,5$; iyimser yaklaşım $1,82 \pm 0,6$; çaresiz yaklaşım $1,26 \pm 0,6$; boyun eğici yaklaşım $1,01 \pm 0,5$ ve sosyal destek arama $1,91 \pm 0,6$ idi. Yılmaz ve Beji'nin [25] araştırma sonuçları da çalışma sonuçlarımıza çok benzer olarak; SBÇTÖ alt boyutları puan ortalamalarını kendine güvenli yaklaşım 2,0 $\pm 0,5$; iyimser yaklaşım $1,7 \pm 0,5$; çaresiz yaklaşım $1,1 \pm 0,5$; boyun eğici yaklaşım $1,0 \pm 0,5$ ve sosyal destek arama $1,9 \pm$ 0,6 olarak bulmuşlardır.

Çalışmada gebelerin yaş gruplarına göre SBTÖ alt boyutları arasında Yılmaz ve Beji’nin [25] çalışmasında olduğu gibi anlamlı bir fark bulunmamıştır. Bazı araştırmalarda ise gebelerin yaşının, eğitim düzeyinin ve sosyoekonomik durumlarının stresle baş etme tarzlarını önemli ölçüde etkilediği belirlenmiştir [29, 30, 50]. Borcherding [51] yaş ile baş etme şekilleri arasında negatif ilişki olduğunu göstermiştir. Daha eğitimli gebelerin boyun eğici ve çaresiz yaklaşım puan ortalamaları daha düşükken, sosyal destek arama boyutunda ise yüksek olması Yılmaz ve Beji'nin [25] çalışmasında elde edilen sonuçları destekler niteliktedir.

Çekirdek ailede yaşayan gebelerin stresle başa çıkmada kendine güvenli yaklaşım, geniş ailede yaşayanların ise çaresiz yaklaşım tarzını kullandıkları belirlenmiştir. Geniş aile yapısına sahip gebelerin kendisi ile ilgili ve aile içi verilecek kararlarda etkin söz sahibi olamayabileceğini bu durumda gebelerin kendine olan güvenlerinin azalabileceği ve çaresizlik hissedebileceği düşünülebilir. Geniş ailede gebenin yalnız olmadığı sorunlarını paylaşabileceği kişilerin olduğu düşünülebilir ancak gebenin yaşadığı sorun karşısında ailedeki birey sayısından çok bu bireylerin gebeye destek olabilecek yetenek ve yeterlilikte olması önemlidir. Gebenin yaşadığı sorunlar karşısında destek kişilerin olmayışı anksiyete oluşturabilir, artan anksiyete düzeyi gebenin sorunlarla sağlıklı baş etmesini olumsuz etkileyebilir [45]. Stresle başa çıkmada çalışmayan gebeler boyun eğici ve çaresiz yaklaşım tarzını tercih etmektedir. Yılmaz ve Beji'nin [25] çalışma sonucu elde ettiğimiz bu bulguyla örtüşürken, Borcherding [51] çalışma durumunun stresle başa çıkma tarzlarını etkilemediğini bildirmiştir. Bu farklılık çalışmanın farklı bir kültürde yapılmış olmasından kaynaklanıyor olabilir.

Borcherding [51] çalışmasında düşük gelir düzeyine sahip gebelerin sorunlarla başa çıkmada daha çok kaçınmacı tarzı tercih ettikleri, problemden ve insanlarla bir arada olmaktan kaçınmak için uyumayı seçtikleri belirtilmiş, Yali ve Lobel [50] de düşük gelir düzeyine sahip gebelerin alkol, sigara gibi maddeleri kullanarak olumsuz bir başa çıkma yöntemini tercih ettiklerini bildirmişlerdir. Çalışmada gelirini giderinden az algilayan gebelerin stresle baş ederken Yılmaz ve Beji'nin çalışmasında [25] olduğu gibi boyun eğici ve çaresiz yaklaşım tarzını kullandıkları belirlenmiştir. Çalışmada üç ve üzeri gebelik yaşayan kadınların stresle başa çıkmada boyun eğici yaklaşım tarzını kullandıkları belirlenmiş, Yılmaz ve Beji [25] ise gebe kadınların gebelik sayısına göre SBTÖ alt boyutlarının puan ortalamaları arasında anlamlı fark saptamamıștır. Bu farklılık çalışmanın değişik bölge ve kültürel özelliklerdeki kadınlarla yapılmış olmasından kaynaklanabilir. Okanlı ve ark. [52] çalışmasında olduğu gibi bu çalışmada gebelik sayısı ile sosyal destek arama puan ortalamaları arasındaki fark önemsiz bulunurken ilk gebeliklerde sosyal destek puanları yüksek bulunmuştur. Yılmaz ve Beji’nin [25] çalışma sonucuyla uyumlu olarak çalışmada çocuğu olmayan grupta bulunan kadınların iyimser yaklaşım tarzını kullandıkları görülmüş, yaşayan çocuk sayısı iki ve üzeri olanların ise boyun eğici yaklaşım tarzını tercih ettikleri saptanmıştır. 
Sağlıklı gebelik sürecinde gebeliğin istenen zamanda olması, gebeliğe hazır oluşluk önemlidir. Çalışmada gebelerin gebe kalmayı planlama durumlarına göre stresle başa çıkma tarzları arasında anlamlı fark saptanmamasına rağmen Yılmaz ve Beji'nin [25] çalışmasında ise planlı gebelik yaşayanların boyun eğici yaklaşımı tercih ettikleri bulunmuştur. $\mathrm{Bu}$ farklılık örneklem grubunun, çalışma yönteminin, çalışılan bölgenin farklı olmasından kaynaklanabilir.

Çalışmada gebelik kaybı yaşayanların boyun eğici yaklaşım tarzını kullandıkları bulunmuştur. Kayıp yaşamakla birlikte gebelerin sosyal destek aramadığı, yapabilecekleri bir şey olmadığını düşünerek boyun eğici yaklaşımı daha fazla kullandığı, suçluluk hissine bağlı kendine olan güvenin azaldığı söylenebilir. Boyun eğici yaklaşım tarzının kullanımının pekişmesinde yaşanan gebelik kayıplarının sayısı da önemli olabilir. Yılmaz ve Beji [25] yaşanan kayıp sayısına göre sosyal destek arama, boyun eğici ve çaresiz yaklaşım boyutunda fark saptamıştır.

Gebelik izlemlerini düzenli olarak yaptıranların kendine güvenli ve sosyal destek arama, düzenli olarak izlem yaptırmayanların ise çaresiz ve boyun eğici yaklaşım tarzını kullandıkları görülmüştür. Kendine güvenli, olaylara pozitif bakan sosyal destekleri güçlü olan kadınların bu yaklaşımları kullandığı ve izlemlerini düzenli olarak yaptırdığı, kendini çaresiz hisseden, destekleri zayıf, boyun eğici kişilerin ise gebelik izlemlerini düzenli olarak yaptırmayıp kaderci davrandıkları söylenebilir. Gebelerin karşılaştıkları sorunlarla etkili bir şekilde mücadele edebilmeleri için desteğe gereksinimleri vardır. Destekleyici sistemlerin varlığı kendini iyi hissetme duygularını, kişisel denetimi ve pozitif duygulanımı kuvvetlendirerek gebeliğe bağlı değişikliklerin daha az stresli olarak algilanmasına yardımcı olur [52]. Gebelik izlemlerini devlet, üniversite ve özel hastanede karışık olarak yaptıran gebelerin stresle başa çıkmada sosyal destek arama tarzını kullandıkları görülmüştür. Kendine güvenli yaklaşım tarzını kullanan gebelerin gebe olduğunu öğrendiğinde mutluluk ve sevinç yaşadıkları görülmektedir. Bu sonucu bu gebelerin planl, isteyerek gebelik yaşamalarına, sosyal destek sistemlerinin güçlü olmasına bağlı olarak kendilerine güvenli yaklaşım tarzını tercih ettiklerini düşünebiliriz.

Kişinin stresle başa çıkma tarzları, ruh sağlığı acısından koruyucu rol oynamaktadır. Bazı stresle başa çıkma tarzları stresle ilişkili negatif duyguları düzenleyerek alternatif çözümler üreten koruyucu bir işlev olarak yardım edebilir, bazen de stresin etkilerini kötüleştirerek uyum sorunlarına yol açabilir [53]. Kişinin stresle baş etme becerisi anksiyete ve depresyonun belirleyici olarak düşünülebilir. Çalışmada stresle başa çıkmada kendine güvenli yaklaşım, iyimser yaklaşım ve sosyal destek arama tarzını kullanan gebelerin depresyon riskinin düşük, boyun eğici ve çaresiz yaklaşım tarzını kullananların ise depresyon riskinin ve anksiyete düzeyinin yüksek olduğu görülmüştür (Tablo 3). Çalışma sonucuyla uyumlu olarak Gourounti ve ark. [44] yaptığg çalışmada gebelerin stresle baş etme becerileri ile anksiyete ve stres arasındaki ilişki anlamlı bulunmuş, olumsuz baş etme yöntemleri ile anksiyete ve depresyon arasında pozitif, olumlu baş etme yöntemleri arasında ise negatif ilişki belirlenmiştir. Greenberg ve ark. [54] da kendine güveni yüksek olan gebelerin daha az anksiyete yaşama eğiliminde olduğunu saptamışlardır.

Çalışma sonucunda; sosyal destek arama tarzını kullanan gebelerde depresyon riskinin azaldığ 1 belirlenmiştir (Tablo 3). Orr [55] sosyal desteği olan gebelerin gebelik esnasındaki olumsuz değişikliklerden fazla etkilenmediğini, sosyal desteği olmayanlara göre daha doyumlu bir gebelik yaşadıklarını ortaya koymuştur. Bazı çalışmalarda da depresyon ya da depresif belirtilerin şiddetiyle sağlık sistemine yönelme ve yardım arama davranışı arasında pozitif ilişki gösterilmiştir [56-58]. Depresyon varlığının veya depresif belirti düzeyi yüksekliğinin stresle başa çıkma sürecinde çaresizlik içeren ve pasif başa çıkma tarzlarını kullanma eğilimini artırması yanında, pasif başa çıkma tarzlarını daha çok kullanan bireylerin depresyon geliştirmeye daha yatkın oldukları da söylenebilir. 
Gebelerin stresle başa çıkmada kendine güvenli yaklaşım, iyimser yaklaşım ve sosyal destek arama tarzını kullanmaları durumunda depresyon riski düşmekte, buna karşılık boyun eğici ve çaresiz yaklaşım tarzını kullanan gebelerde depresyon riski ve anksiyete düzeyi yükselmektedir. Gebelik dönemi boyunca depresyon ve anksiyete riskinin düşürülebilmesine yönelik gebelerin stresle başa çıkmada olumlu yaklaşım tarzını benimsemelerinde, başta ebeler olmak üzere diğer sağlık çalışanlarının bu konuda duyarlı olmaları gerekmektedir.

\section{Kaynaklar}

1. Kara B, Çakmaklı B, Nacak E, Türeci F. Doğum sonrası depresyon. STED 2001; 10: 333-4.

2. Ekuklu G, Tokuc B, Eskiocak M, Berberoglu U, Saltik A. Prevalence of postpartum depression in Edirne, Turkey, and related factors. J Reprod Med 2004; 49: 908-14.

3. Üst ZD, Pasinlioğlu T, Özkan H. Doğum eyleminde gebelerin anksiyete düzeylerinin incelenmesi. Anadolu Hemşirelik ve Sağlık Bilimleri Dergisi 2013; 16: 110-5.

4. Rossi N, Bassi L, Campanini D, Delfino MD. Maternal anxiety and childbirth. Clin Exp Obstet Gynecol 1993; 18: 19-25.

5. Turan TE, Çetin N. Doğum ve anksiyete üzerine kıyaslamalı bir çalışma. Türkiye'de Psikiyatri 2001; 3: 47-51.

6. Pehlivan K. Kadın Psikiyatrik Hastalarının cinsel yaşam, evlilik, aile planlaması ve kontrasepsiyon, gebelik ve çocuk sahibi olması, AIDS, cinsel yolla bulaşan hastalıklar açısından riskli davranışlarının genel popülasyonla karşılaştırılmalı çalışması. Uzmanlık tezi. Bakırköy Ruh Sağlığı ve Sinir Hastalıkları Eğitim Araştırma Hastanesi, İstanbul, 2004.

7. Lee AM, Lam SK, Sze Mun Lau SM, Chong CS, Chui HW, Fong DY. Prevalence, course, and risk factors for antenatal anxiety and depression. Obstet Gynecol 2007; 110: 1102-12.

8. Da Costa D, Larouche J, Dritsa M, Brender W. Variations in stress levels over the course of pregnancy: factors associated with elevated hassles, state anxiety and pregnancy-specific stres. J Psychosom Res 1999; 47: 609-21.

9. Genez D. Hamile kadınların kaygı düzeyleri. Ondokuz Mayıs Üniversitesi Sosyal Bilimler Enstitüsü, Samsun 2002.

10. Karataylı S. Gebelerde trimesterler arası depresyon, anksiyete, diğer ruhsal belirtiler ve yaşam kalitesi düzeyleri. Uzmanlık tezi, Selçuk Üniversitesi Meram Tıp Fakültesi, Konya 2007.

11. Figueiredo B, Conde A. Anxiety and depression in women and men from early pregnancy. Arch Womens Ment Health 2011; 14: 247-55.

12. Tekgöz İ, Sunay D, Çaylan A, Kısa C. Gebeliğin son 3 ayında anksiyete bozukluğu ve ilişkili faktörlerin değerlendirilmesi. Türk Aile Hek Derg 2009; 13: 132-6.

13. Şahin EM, Kılıçarslan S. Son trimester gebelerin depresyon ve kaygı düzeyleri ile bunları etkileyen etmenler. Trakya Üniversitesi Tıp Fakültesi Dergisi 2010; 27: 51-8.

14. Kurki T, Hiilesmaa V, Raitasalo R, Mattila H, Ylikorkala O. Depression and anxiety in early pregnancy and risk for preeclampsia. Obstetrics\&Gynecology 2000; 95: 487-90.

15. Honjo S, Arai S, Kaneko H, Ujiie T, Murase S, Sechiyama H. Antenatal depression and maternal-fetal attachment. Psychopathology 2003; 36: 304-11.

16. Marcus SM, Flynn HA, Blow FC, Barry, KL. Depressive symptoms among pregnant women screened in obstetrics settings, Journal of Women's Health 2003; 12: 373-80.

17. Armstrong DS. Impact of Prior Perinatal Loss on Subsequent Pregnancies JOGNN 2004; 33: 765-73. 
18. Lara MA, Le HN, Letechipia G, Hochhausen L. Prenatal depression in latinas in the U,S, and Mexico. Matern Child Health J 2009; 13: 567-76.

19. Seimyr L, Sjögren B, Welles-Nyström B, Nissen E. Antenatal maternal depressive mood and parental-fetal attachment at the end of pregnancy. Arch Womens Ment Health 2009; 12: 269-79.

20. Cebeci SA, Aydemir Ç, Göka E. Puerperal dönemde depresyon semptom prevalansı: Obstetrik risk faktörleri, kaygı düzeyi ve sosyal destek ile ilişkisi. Kriz Dergisi 2002; 10: 11-8.

21. Akbaş E, Vırıt O, Kalenderoğlu A, Savaş AH, Sertbaş G. Gebelikte sosyodemografik değişkenlerin kaygı ve depresyon düzeyleriyle ilişkisi. Noropsikiyatri Arşivi 2008; 45: 85-91.

22. Erbil N, Oruç H, Karabulut A. Gebelikte depresyon ve etkileyen faktörlerin belirlenmesi. Turkiye Klinikleri J Gynecol Obst 2009; 19: 67-74.

23. Karaçam Z, Ançel G. Depression, anxiety and influencing factors in pregnancy: a study in a Turkish population. Midwifery 2009; 25: 344-56.

24. Arslan B. Gebelerde Anksiyete ve Depresyonla İlişkili Sosyodemografik Özellikler. S.D.Ü Aile Hekimliği Anabilim Dalı. Uzmanlık Tezi, Isparta, 2010.

25. Yılmaz DS, Beji KN. Gebelerin stresle başa çıkma, depresyon ve prenatal bağlanma düzeyleri ve bunları etkileyen faktörler. Genel Tıp Dergisi 2010; 20 : 99-108.

26. Orr ST, James SA, Blackmore PC. Maternal prenatal depressive symptoms and spontaneous preterm births among African-American women in Baltimore, Maryland. Am J Epidemiol 2002; 156: 797-802.

27. Altın EG. Perinatal depresyon tedavisinde kişilerarası terapi. Psikiyatride Güncel Yaklaşımlar-Current Approaches in Psychiatry 2012; 4: 188-203.

28. Yeşiltepe OÜ. Yüksek riskli gebelerde hemşirelik bakımı, Perinatoloji Dergisi 2004; 12: 11-5.

29. Hamilton JG, Lobel M. Types, patterns, and predictors of coping with stress during pregnancy: Examination of the Revised Prenatal Coping Inventory in a diverse sample. Journal of Psychosomatic Obstetrics \& Gynecology 2008; 29: 97-104.

30. Huizink AC, de Medina PG, Mulder EJ, Visser GH, Buitelaar JK. Coping in normal pregnancy. Annals of Behavioral Medicine 2002; 24: 132-40.

31. Selvi P. Sivas ilinde yapılacak saha araştırmalarında kullanılmak üzere çeşitli sayı ve nitelikte örnekleme planının geliştirilmesi. Yüksek lisans tezi, Cumhuriyet Üniversitesi Sağlık Bilimleri Enstitüsü, Sivas, 2008.

32. Şahin HN, Durak A, Stresle başa çıkma tarzları ölçeği; üniversite öğrencileri için uyarlanmas1. Türk Psikoloji Dergisi 1995; 10: 56-73.

33. Yılmaz DS, Beji KN. Prenatal bağlanma envanterinin Türkçe'ye uyarlanması: güvenilirlik ve geçerlilik çalışması. Anadolu Hemşirelik ve Sağlık Bilimleri Dergisi 2013; 16: 103-9.

34. Ulusoy M, Şahin NH, Erkmen H. Turkish version of the Beck Anxiety Inventory: Psychometric properties. J Cogn Psychother 1998; 12: 163-72.

35. Nur N, Çetinkaya S, Bakır DA, Demirel Y. Sivas il merkezindeki kadınlarda postnatal depresyon prevalansi ve risk faktörleri. CÜ Tıp Fakültesi Dergisi 2004; 26: 55-9.

36. Gözüyeşil YE, Şirin A, Çetinkaya Ş. Gebe kadınlarda depresyon durumu ve bunu etkileyen etmenlerin incelenmesi. Firat Sağlık Hizmetleri Dergisi 2008; 3: 39-66.

37. Goecke TW, Voigt F, Faschingbauer F, Spangler G, Beckmann MW, Beetz A. The association of prenatal attachment and perinatal factors with pre-and postpartum depression in first-time mothers. Arch Gynecol Obstet 2012; 286: 309-16.

38. Leigh B, Milgrom J. Risk factors for antenatal depression, postnatal depression and parenting stres. BMC Psychiatry 2008; 8.

39. Hart R, McMahon CA. Mood state and psychological adjustment to pregnancy. 
Arch Womens Ment Health 2006; 9: 329-37.

40. Babadağlı B, Gebelik yaşının gebelikte yaşanan fizyolojik ve psikolojik değişikliklere etkisi. Atatürk Üniversitesi Hemşirelik Yüksekokulu Dergisi 2008; 11: 96-105.

41. Arslantaş H, Ergin F, Akdolun BN. Aydın il merkezinde doğum sonrası depresyon sıklığı ve ilişkili risk etmenleri. ADÜ Tıp Fakültesi Dergisi 2009; 10: 13-22.

42. Efe YŞ, Taşkın L, Eroğlu K. Türkiye'de postnatal depresyon ve etkileyen faktörler. J Turkish-German Gynecol Assoc 2009; 10: 14-20.

43. Sevil DÜ, Saruhan A, Ertem G, Kavlak O. Kadınların doğum öncesi ve doğum sonrası anksiyete ve depresyon düzeylerinin ve bunlara etki eden faktörlerin incelenmesi. DEÜ Tıp Fakültesi Dergisi 2004; 18: 67-76.

44. Gourounti K, Anagnostopoulos F, Lykeridou K. Coping strategies as psychological risk factor for antenatal anxiety, worries, and depression among Greek women. Arch Womens Ment Health 2013; 16: 353-61.

45. Sertbaş G. Gebelerde doğum öncesi ve doğum sonrası dönemlerde durumluk sürekli kaygı düzeylerinin incelenmesi. Ege Üniversitesi Sağlık Bilimleri Enstitüsü, Doktora Tezi, İzmir, 1998.

46. Dülgerler Ş, Engin E, Ertem G. Gebelerin ruhsal belirti dağılımlarının incelenmesi. Ege Üniversitesi Hemşirelik Yüksek Okulu Dergisi 2005; 21: 11526.

47. Symon A. A review of mothers' prenatal and postnatal quality of life. Health Qual Life Outcomes 2003; 1, 38.

48. Akkoca, Y. Doğum sonrasında anne-bebek bağlanmasını etkileyen faktörler. GÜ Tıp Fakültesi Psikiyatri Anabilim Dalı, Uzmanlık Tezi, Ankara, 2009.

49. Andersson L, Sundstrom-Poromaa I, Wulff M, Astrom M, Bixo M. Implications of antenatal depression and anxiety for obstetric outcome. Am J Obstet Gynecol 2004; 104: 467-76.

50. Yali AM, Lobel M. Coping and distress in pregnancy: An investigation of medically high risk women. Journal of Psychosomatic Obstetric and Gynecology 1999; 20: 39-52.

51. Borcherding KE. Coping in healthy primigravidae pregnant women. JOGNN 2009; 38: 453-62.

52. Okanlı A, Tortumluoğlu G, Kırpınar İ. Gebe kadınların ailelerinden aldıkları sosyal destek ile problem çözme becerileri arasındaki ilişki. Anadolu Psikiyatri Dergisi 2003; 4: 98-105.

53. Öngen D. Relationships between coping strategies and depression among Turkish adolescents. Social Behavior and Personality 2006; 34: 181-96.

54. Greenberg J, Solomon S, Pyszczynski T, Rosenblatt A, Burling J, Lyon D. Why do people need self-esteem? Converging evidence that self-esteem serves an anxiety-buffering function. Journal of Personality and Social Psychology 1992; 63: 913-22.

55. Orr ST. Social support and pregnancy outcome: A review of the literature. Clinical Obstetrics and Gynecology 2004; 47: 842-55.

56. Ravindran AV, Matheson K, Griffiths J, Merali Z, Anisman H. Stress, coping, uplifts, and quality of life in subtypes of depression: A conceptual frame and emerging data. J Affect Disord 2002; 71: 121-30.

57. Ayrancı Ü, Yenilmez Ç. Eskişehir ilinde birinci basamak sağlık kurumlarında verilen ruh sağlığı hizmetlerinin değerlendirilmesi. Turk Psikiyatri Derg 2002; 13: $115-24$.

58. Wilde JD, Soyez V, Broekaert E, Rosseel Y, Kaplan C, Larsson J. Problem severity profiles of substance abusing women in European Therapeutic Communities: Influence of psychiatric problems. J Subst Abuse Treat 2004; 26: 243-51. 